\title{
Evaluation of Microbial Biocontrol Agents and Fungicides against Alternaria helianthi Causing Leaf Blight of Sunflower
}

\author{
G. Vijayalakshmi*, K. Karuna and G. Mahadevaswamy \\ Department of Plant Pathology, University of Agricultural Sciences, \\ Bengaluru - 560065, India \\ *Corresponding author
}

\section{A B S T R A C T}

\section{Keywords \\ Sunflower, Leaf blight, Alternaria helianthi, \\ Biocontrol, Fungicides}

Article Info

Accepted:

20 December 2017

Available Online:

10 January 2018
The efficacy of twelve microbial biocontrol agents viz., Trichoderma viride $T$. viride strain $16 T$. viride strain $60 \mathrm{~T}$. harzianum T. harzianum strain $2 T$. harzianum strain 55 Pseudomonas fluorescens and Bacillus subtilis were evaluated by dual culture technique against Alternaria helianthi. In vitro efficacy of six fungicides viz., Mancozeb, Iprodione, Propiconozole, Chlorothalonil, Hexaconozole and Difenconozole were evaluated by food poison technique. Among the biocontrol agents, maximum inhibition of radial growth of $A$. helianthi was observed in observed in $T$. viride $(85.33 \%)$ which was followed by $T$. viride strain $16(79.33 \%)$, and T. harzianum (76.44\%). Among the fungicides, Propiconozole recorded maximum inhibition of mycelial growth of $A$. helianthi $(90.47 \%)$ followed by Mancozeb (90.42\%) and Iprodione+Caebendazim (89.75\%). In in vivo evaluation spraying of T. viride @ 1:0 dilution was effective and Propiconozole @ 0.1\% was found effective.

\section{Introduction}

Sunflower (Helianthus annuus L.) is an important oilseed crop, ranks second to soybean in worldwide vegetable oil production. Commercially available sunflower contains 39 to 49 per cent oil in the seed. It is extensively grown in Argentina, France, Spain, USA, China, Ukraine and India. In India, sunflower occupies the fourth place among oilseed crops in terms of acreage and production. The area under sunflower cultivation in India was $0.72 \mathrm{~m}$ ha, with a total production of $0.50 \mathrm{~m} \mathrm{t}$ and productivity of 692 $\mathrm{kg} / \mathrm{ha}$ (Anonymous, 2013). Over 70 per cent of the sunflower crop is being grown across Karnataka, Maharastra and Andhra Pradesh. In Karnataka it occupies an area of about 3.84 lakh ha with a production of 1.93 lakh tonnes and productivity of $503 \mathrm{~kg} / \mathrm{ha}$.

Among the major diseases of sunflower, Alternaria blight caused by Alternaria helianthi (Hansf.) Tubaki and Nishihara is most devastating disease in Karnataka. The disease is known to cause more than 80 per cent of yield loss under severe epiphytotic conditions. Several effective pesticides have been recommended for the control of Alternaria leaf blight but they are not 
considered to be long term solutions, due to concerns of expense, exposure to heal the risk, fungicide residue and other environmental hazards. In the recent past most of the work has been directed towards biological disease management, use of antagonistic fungi appears logical and safe (Latha et al., 2009). Bio control agents compete with fungal phytopathogens either competing for nutrients and space, or indirectly modifying environmental conditions, promoting plant growth and plant defense mechanism and antibiosis, or directly through mechanisms such as mycoparasitism (Shakeri and Foster, 2007; Reino et al., 2008). Trichoderma spp. suppresses disease by antagonizing the pathogen (Shah and Nasreen, 2011). In the present study some of the new chemicals and microbial biocontrol agents were tested under laboratory and field conditions to find out their efficacy against A.helianthi.

\section{Materials and Methods}

In vitro evaluation of biocontrol agents and fungicides against $A$. helianthi

Six fungal and two bacterial antagonists were evaluated in vitro against $A$. helianthi applying dual culture technique. In dual culture technique, $20 \mathrm{ml}$ of sterilized and cooled potato dextrose agar medium was poured into sterilized petriplates. Fungal antagonists were evaluated by inoculating the pathogen at one side of the petriplate and the antagonist was inoculated exactly on opposite side of the same plate by leaving $3-4 \mathrm{~cm}$ gap. For this, actively growing cultures were used. In case of bacterial antagonist evaluation, two mycelia discs of pathogen were inoculated and bacterial antagonist was streaked at the centre of the plate. Each treatment was replicated three times. After required period of incubation i.e., after mycelia growth in control plate reached $90 \mathrm{~mm}$ diameter, the radial growth of pathogen was measured. Per cent inhibition of the test fungus over untreated control was calculated by applying the formula (Arora and Upadhyay, 1978).

$$
\mathrm{I}=\frac{\mathrm{C}-\mathrm{T}}{\mathrm{C}} \times 100
$$

$\mathrm{I}=$ Per cent growth inhibition

$\mathrm{C}=$ Colony growth in control plate

$\mathrm{T}=$ Colony growth in intersecting plate

\section{In vitro evaluation of fungicides}

Efficacy of six fungicides against $A$. helianthi was assessed by food poison technique. Five mm diameter of culture disc of $A$. helianthi was kept at the center of each Petri plate containing the fungicides of required concentration dissolved in PDA. Three replications were maintained. The plates were incubated at $27 \pm 1^{\circ} \mathrm{C}$ for ten days and colony diameter was recorded.

Chemical fungicides used with their concentration are presented in table 1 .

Per cent inhibition of mycelial growth was calculated by using the formula

$$
\mathrm{I}=\frac{\mathrm{C}-\mathrm{T}}{\mathrm{C}} \times 100
$$

$\mathrm{I}=$ Per cent inhibition of mycelium.

$\mathrm{C}=$ growth of mycelium in control.

$\mathrm{T}=$ Growth of mycelium in treatment.

\section{Field evaluation of biocontrol agents and fungicides against Alternaria leaf blight}

Field experiment was conducted at Zonal Agricultural Research Station during kharif 2013-14 to know the efficacy of fungicides and different dilutions of $T$. viride which was found effective in vitro and under glass house against Alternaria blight of sunflower.

Plot size: $4.8 \mathrm{~m}$ x $3.6 \mathrm{~m}$

Hybrid: KBSH-44 
Space: $(60 \times 30) \mathrm{cm}$

Design: RCBD

Treatment: 7

Replication: 3

\section{Treatments}

$\mathrm{T} 1$ = Seed treatment and spraying with $T$. viridae@1:0 dilution

$\mathrm{T} 2=$ Seed treatment and spraying with $T$. viridae @ 1:1 dilution

$\mathrm{T} 3=$ Seed treatment and spraying with $T$. viridae@1:2 dilution

T4 =Seed treatment and spraying with

Propiconozole @ 0.1\%

T5= Seed treatment and spraying with Iprodione+Carbendazim @ 0.2\%

T6 $=$ Seed treatment and spray with Mancozeb @ $0.3 \%$

$\mathrm{T} 7=$ Control

Mancozeb, Iprodione, $T$. viride were treated to seeds and two sprays were given at 45 and 60 DAS. Propiconozole was sprayed thrice at 30 , 45 and 60 DAS. Observations on growth parameters like plant height, number of leaves and stem girth were recorded at 60 DAS. Per cent disease severity was recorded at $50 \%$ of flowering stage. Yield of each treatment was calculated separately. The data were analyzed statistically.

\section{Results and Discussion}

\section{In vitro evaluation of bioagents by dual culture technique}

Six fungal and two bacterial bioagents were evaluated in vitro against $A$. helianthi applying dual culture technique and using Potato dextrose agar (PDA) as basal medium. Results (Table 2) revealed that all the bioagents evaluated exhibited fungistatic activity and significantly inhibited mycelial growth of $A$. helianthi. The least growth of the pathogen was observed in $T$. viride $(0.66 \mathrm{~cm})$ followed by $T$. viride strain $16(0.93 \mathrm{~cm})$ and $T$. harzianum $(1.06 \mathrm{~cm})$.Maximum inhibition of mycelial growth of $A$. helianthi was recorded in $T$. viride $(85.33 \%)$, followed by $T$. viride strain 16 (79.33\%), T. harzianum (76.44\%), and the least inhibition (49.77\%) of mycelial growth was noticed in $P$. fluorescens. Thus, all the biocontrol agents evaluated in vitro were found fungistatic against A. helianthi; the fungal bioagent was found effective than bacterial bioagent, for inhibition of test pathogen are in conformity to those reported earlier by several workers (Imtiaj and Lee, 2008; Vihol et al., 2009; Ambuse et al., 2009).

Table.1 In vitro evaluation of bioagents against $A$. helianthi by dual culture technique

\begin{tabular}{|c|c|c|}
\hline Treatments & Radial growth of pathogen $(\mathrm{mm})$ & Per cent inhibition over control (\%) \\
\hline Alternaria helianthi & 45 & \\
\hline T. viride & 6.6 & 85.33 \\
\hline T. viride 16 & 9.3 & 79.33 \\
\hline T. viride 60 & 16 & 64.44 \\
\hline T. harzianum & 10.6 & 76.44 \\
\hline T. harzianum 2 & 15.6 & 65.33 \\
\hline T. harzianum 55 & 18.6 & 58.66 \\
\hline B. subtilis & 21.2 & 52.88 \\
\hline P. fluorescens & 22.6 & 49.77 \\
\hline S. Em \pm & 0.16 & 2.03 \\
\hline C.D @ 1\% & 0.671 & 8.55 \\
\hline
\end{tabular}


Table.2 In vitro evaluation of fungicides against $A$. helianthi by food poison technique

\begin{tabular}{|c|c|c|c|c|c|}
\hline \multirow{2}{*}{ SI.No. } & \multicolumn{4}{|c|}{ Per cent inhibition (\%) } \\
\cline { 2 - 5 } & & \multicolumn{4}{|c|}{ Concentration (ppm) } \\
\hline 1 & Mancozeb & 50 & 100 & 250 & 500 \\
\hline 2 & Iprodione+Carbendazim & 79.68 & 84.12 & 89.84 & 90.42 \\
\hline 3 & Propiconazole & 72.94 & 75.23 & 88.18 & 89.75 \\
\hline 4 & Chlorothalonil & 65.20 & 90.47 & 90.47 & 90.47 \\
\hline 5 & Difenoconazole & 58.86 & 61.39 & 78.15 & 88.51 \\
\hline 6 & Hexaconazole & 49.84 & 51.75 & 56.03 & 68.19 \\
\hline & S.Em \pm & 1.2 & 0.79 & 1.01 & 62.15 \\
\hline & C.D @ 1\% & 5.36 & 3.54 & 4.54 & 8.2 \\
\hline
\end{tabular}

Table.3 Effect of seed treatment with $T$. viride and fungicides on growth and yield parameters of sunflower

\begin{tabular}{|c|c|c|c|c|c|c|}
\hline & Treatments & $\begin{array}{l}\text { Plant height } \\
(\mathrm{cm})\end{array}$ & $\begin{array}{l}\text { No. of } \\
\text { leaves }\end{array}$ & $\begin{array}{l}\text { Stem girth } \\
(\mathrm{cm})\end{array}$ & $\begin{array}{c}\text { Seed yield (Kg } \\
\left.\mathrm{ha}^{-1}\right)\end{array}$ & $\begin{array}{c}\text { Disease } \\
\text { severity }(\%)\end{array}$ \\
\hline T1: & T.viride@1:0 dilution & 173.15 & 24.65 & 2.15 & 1851.27 & 23.23 \\
\hline T2: & T.viride@1:1 dilution & 170.45 & 22.75 & 1.95 & 1776.04 & 27.98 \\
\hline T3: & T.viride@1:2 dilution & 164.05 & 21.95 & 1.88 & 1759.25 & 33.74 \\
\hline T4: & Propiconozole @ 0.1\% & 189.12 & 27.37 & 2.42 & 2181.71 & 9.85 \\
\hline T5: & Iprodione+Carbendazim @ 0.2\% & 180.40 & 24.65 & 2.19 & 1942.71 & 18.11 \\
\hline T6: & Mancozeb@0.3\% & 185.65 & 25.45 & 2.29 & 2160.30 & 13.91 \\
\hline T7: & Control & 151.93 & 20.05 & 1.68 & 1472.80 & 46.03 \\
\hline \multicolumn{2}{|c|}{ S.Em } & 2.57 & 0.73 & 0.94 & 1.27 & 0.38 \\
\hline \multicolumn{2}{|c|}{ C.D@5\% } & 7.99 & 2.27 & 2.92 & 3.78 & 0.53 \\
\hline \multicolumn{2}{|c|}{ CV (\%) } & 20.9 & 11.6 & 12.9 & 14.54 & 11.7 \\
\hline
\end{tabular}

\section{In vitro evaluation of fungicides}

Application of fungicides for the management of plant diseases in sunflower has become an inevitable method as no resistant cultivars for Alternaria blight are available. Among the six fungicides evaluated through food poison technique, the results revealed that Propiconozole and Mancozeb (50, 100, 250 and $500 \mathrm{ppm})$ were effective. Iprodione+Carbendazim and Chlorothalonil were also found effective to some extent.

The results obtained in present studies in respect of in vitro effect of fungicides on mycelial growth inhibition of the test pathogen for the combination of SAAF, Azoxystrobin, Mancozeb, Propiconazole, Chlorothalonil and Hexaconazole fungicides effect is similar with earlier workers (Akbari and Parakhia, 2007; Mathivanan and Prabavathy, 2007; Dighule et al., 2011).
Effect of seed treatment and spraying with different dilutions $T$. viride and fungicides on growth, yield parameters and disease severity of sunflower

The results presented in Table 3 revealed that all treatments were found significantly superior over the control. Among the different concentrations of $T$. viride, $\mathrm{T}_{1}$ (seed treatment and spraying with $T$. viride at 1:0 dilution) recorded maximum stem girth of $2.15 \mathrm{~cm}$, an yield of $1851.27 \mathrm{~kg} / \mathrm{ha}$ and recorded disease severity of 23.23 per cent. These results are in accordance with the results obtained by earlier research workers in sunflower (Arunakumara $e t$ al., 2010; Reshu and Mahmud Khan, 2012).

Among the three fungicides evaluated, spraying with Propiconozole $(0.1 \%)$ recorded highest yield of $2181.71 \mathrm{~kg} / \mathrm{ha}$ and a least disease severity of 9.85 per cent followed by T6 (seed treatment and spraying with Mancozeb) 
13.91per cent and T5 (seed treatment and spraying with Iprodione+Carbendazim) 18.11 per cent. The highest disease severity (46.03 per cent) was recorded in control (T7). These results are in accordance with the results obtained by earlier research workers in sunflower (Murumkar et al., 2007; Singh and Singh, 2007; Mesta et al., 2011).

\section{References}

Anonymous (2013) Ann. Progr. Rep. Of AICRP on oilseeds- sunflower for the year 2012-13, DOR, ICAR, Hyderabad, India.

Latha PT, Anand N, Raghupathi V, Prakasam, Samiyappan R (2009) Antimicrobial activity of Plant extracts and induction of systemic resistence in tomato plants by mixtures of PGPR strains and Zimmu leaf extract against Alternaria solani. Biol. Control. 50: 85-93.

Shakeri J, Foster HA (2007) Proteolytic activity and antibiotic production by Trichoderma harzianum in relation to pathogenicity to insects.Enzyme Microbial. Technol. 40: 961968.

Reino JL, Guerrero R, Hernandez-galan, Collado IG (2008) Secondary metabolites from species of the biocontrol agent Trichoderma. Phytochem. Rev. 7: 89-123.

Shah S, Nasreen S (2011) Evaluation of bioagents against the infection of green mold (Trichoderma spp.) in Pleurotus sajor-caju cultivation. Int. J. Plant Pathol. 2: 81-88.

Arora DK, Upadhyay RK (1978). Effect of fungal staling growth substances on colony interaction. Plant Soil. 49: 685-690.

Imtiaj A, Lee TS (2008) Antagonistic effect of three Trichoderma species on the Alternaria porri, pathogen of onion blotch. World J. Agric.Sci. 4: 13-17.

Vihol JB, Patel KD, Jaiman RK, Patel NR (2009) Efficacy of Plant Extracts, Biological agents and Fungicides Against Alternaria Blight of Cumin. J Mycol Pl. Pathol. 39(3):516-519.

Ambuse MG, Chatage VS, Bhale UN (2012) Influence of Trichoderma spp against Alternaria tenuissima inciting leaf spot of Rumex acetosa L. Bioscience Discovery. 3(2):259-262.

Akbari LF, Parakhia AM (2007) Management of Alternaria alternate causing blight of sesame with fungicides. J. Mycol. Plant Pathol. 37(3):426-430.

Mathivanan N, Prabavathy VR (2007). Effect of carbendazim and mancozeb combination on Alternaria leaf blight and seed yield of sunflower. Arachis Phytopathol. Plant Protect. 40(2):90-96.

Dighule S B, Perane RR, Amile KS, More PE (2011) Efficacy of chemical fungicides and bio-agents against major cotton fungal foliar diseases in vitro. Int. J. Pl. Sci., 6: 247-250.

Arunakumara KT, Kulkarni MS, Thammaiah N, Yashoda H (2010) Fungicidal management of early blight (Alternaria solani) of tomato. Indian Phytopathol. 63(1):96-97.

Reshu, Mahmud Khan (2012) Role of different microbial- origin bioactive antifungal compounds against Alternaria sp. causing leaf blight of mustard. J Plant Pathol. 11(1): 1-9.

Murumkar DR, Indi DV, Gud MA, Shinde SK (2007) Field evaluation of some newer fungicides against leaf spot of safflower caused by Alternaria carthami. Seventh International conference, Wagga Wagga, NSW, Australia, November 3-6.

Singh HK, Singh RB (2007) Integrated management of Alternaria blight of Rapeseed-mustard. Indian Phytopathol. 60(3): 396.

Mesta RK, Benagi VI, Srikant Kulkarni, Basavarajappa MP (2011) Management of Alternaria blight of sunflower through fungicides. Karnataka J. Agric. Sci. 24 (2): 149-152.

\section{How to cite this article:}

Vijayalakshmi, G., K. Karuna and Mahadevaswamy, G. 2018. Evaluation of Microbial Biocontrol Agents and Fungicides against Alternaria helianthi Causing Leaf Blight of Sunflower. Int.J.Curr.Microbiol.App.Sci. 7(01): 2726-2730. doi: https://doi.org/10.20546/ijcmas.2018.701.326 